\title{
Peran Organizational Citizenship Behavior (OCB) dan Budaya Organisasi Dalam Meningkatkan Kinerja Karyawan di UKM Snak Makroni Cap Bintang Desa Mutih Wetan, Kabupaten Demak
}

\author{
Andi Aina Ilmih \\ Universitas Islam Sultan Agung \\ andinazuldina@gmail.com
}

\begin{abstract}
ABSTRAK
The study was conducted on employees of UKM Sank Makroni Cap Bintang, Mutih Wetan Village, Demak Regency. This research includes the type of field research, which is a research study that takes authentic data objectively. Whereas seen from the type, this research is classified as qualitative research using descriptive method. The research was conducted to determine the role of organizational citizenship behavior (OCB) and organizational culture to improve employee performance. There are five aspects in implementing OCB, namely: Altruism, Conscientiousness, Courtesy and Civic Virtue. While the role of organizational culture will improve employee performance through seven aspects in its implementation, namely: innovation and courageous risk taking, attention, people orientation, team orientation, aggressiveness, stability.
\end{abstract}

Keywords: organizational citizenship Behavior (OCB), organizational culture and employee performance

\section{A. PENDAHULUAN}

Usaha kecil menengah (UKM) merupakan usaha yang banyak dijumpai dan dilakukan oleh orang Indonesia. UKM mulai berkembang pasca terjadi krisis pada tahun 1997 di Indonesia, pada saat itu banyak karyawan yang di PHK sehingga sebagian mereka memutuskan untuk mendirikan usaha sendiri. UKM telah memiliki andil besar dalam pembangunan nasional dan penyerapan tenaga kerja. Namun kalau dilihat dari sisi pengelolaan sumber daya manusianya (SDM) masih mengalami kendala sehingga mengakibatkan kinerja yang kurang maksimal. Hafsah (2004) menyatakan bahwa, masalah UKM adalah sumber daya manusia yang terbatas. Keterbatasan SDM usaha kecil baik dari segi pendidikan formal maupun pengetahuan dan keterampilannya sangat berpengaruh terhadap manajemen pengelolaan usaha. Organisasi atau perusahaan dituntut untuk bisa mengelola SDM / karyawan dengan tepat karena mereka menjadi salah satu faktor penentu keberhasilan.

Unsur orang sangat penting dalam suatu organisasi, karena keberhasilan organisasi sangat tergantung pada kualitas sumber daya manusia. Organisasi diharapkan memiliki karyawan yang berkualitas, sehingga bisa memenangkan kompetisi dalam dunia usaha. Perubahan dibidang ekonomi, politik, sosial dan teknologi bisa memiliki pengaruh yang kuat terhadap sebuah organisasi atau perusahaan. Pengaruh tersebut harus segera direspon organisasi, dengan cara melakukan pembenahan dan perubahan agar dapat bertahan dalam persaingan serta memiliki organisasi yang lebih efektif. Perusahaan juga harus mampu mempertahankan dan meningkatkan kinerja organisasi secara menyeluruh, baik kinerja individu maupun kelompok. 
Karyawan merupakan suatu aset, sehingga perusahaan harus memperhatikan kesejarteraan dengan memberikan reward atas kinerja yang dihasilkan. Dengan perhatian yang diberikan, kinerja karyawan dapat meningkat serta semakin loyal terhadap perusahaan. Organisasi maupun karyawan dalam perusahaan harus terbina dengan baik. Bila karyawan tidak dapat menjalankan pekerjaannya dengan rasa riang dan gembira, maka perusahaan tidak akan bisa mencapai hasil yang diinginkan. Ada beberapa kriteria perilaku karyawan yang bisa membuat organisasi supaya lebih efektif, yaitu : mempunyai sensitifitas sosial yang diwujudkan saling membantu dalam aktifitas kerja, keinginan berpartisipasi dalam kelompok maupun tim kerja, memiliki moral dan kesadaran untuk mencapai tujuan individu maupun perusahaan tanpa melakukan hal yang merugikan antar karyawan. Perilaku dan kriteria karyawan tersebut dikenal dengan Organizational Citizenship Behavior (OCB).

Organizational Citizenship Behavior (OCB) merupakan istilah bagi karyawan yang memberikan penilaian lebih pada pekerjaan yang menjadi tugasnya maupun nilai tambah bagi perusahaan. OCB disebut juga sebagai perilaku extra role sebab perilaku yang diberikan karyawan melebihi tugas utamanya. Dibandingkan dengan perilaku in role, yaitu menjalankan pekerjaan sesuai dengan tugas yang ada dalam job description, yang dihubungkan dengan penghargaan ekstrinsik, maka perilaku extra-role lebih dihubungkan dengan penghargaan intrinsik. Perilaku extra role muncul karena adanya perasaan sebagai bagian dari organisasi dan merasa puas apabila dapat melakukan pekerjaan yang lebih pada organisasi. Penelitian yang dilakukan oleh Deww Zang (2011) dalam Sukmawati mendapatkan hasil yang signifikan, yaitu OCB mempunyai pengaruh positif terhadap kinerja

Budaya organisasi juga bisa mempengaruhi karyawan dalam menjalankan aktifitas kerja khususnya dalam hal : cara bekerja dengan tim, cara memahami gambaran pekerjaan dan cara bertingkah laku. Organisasi harus menciptakan budaya kerja yang kondusif sehingga para karyawan akan merasa aman dan nyaman dalam bekerja. Terciptanya suasa yang positif akan berdampak pada kelancaran dalam pelaksanaan kerja. Luthans dalam Riani, 2011: 8 menyatakan bahwa budaya organisasi yang baik akan menambahkan nilai positif bagi kelancaran kinerja organisasi. Efektifitas dan efisiensi sering dikaitkan dengan kelancaran kerja pelaku organisasi dalam menjalankan tugas. Berdasarkan beberapa penjelasan diatas bisa digaris bawahi, bahwa konsep budaya organisasi adalah sebagai alat untuk meningkatkan kinerja karyawan.

Desa Mutih Wetan merupakan salah satu kelurahan yang ada di Kabupaten Demak, memiliki potensi pada sektor pariwisata, pertanian, perikanan dan terdapat juga usaha kerakyatan (UKM) yang menjadikan potensi desa tersebut. Khususnya disektor usaha kerakyatan, masyarakat di Desa Mutih Wetan dalam hal memproduksi makanan ringan berbasis home industry. Adapun produk yang diproduksi berupa makroni, cemilan usus dan makanan ringan lainnya. Ada tiga UKM didaerah tersebut yang mempunyai produk sejenis, salah satunya "Snak Makroni Cap Bintang" yang memiliki 35 karyawan. Pemasaran dan penjualan produk disamping daerah Demak juga sudah sampai Kudus dan Semarang. Pemilik usaha dalam mengelola karyawannya mengedepankan sikap kekeluargaan sehingga sampai hari ini usaha makanan ringan yang dijalankan masih tetap eksis walaupun banyak jenis cemilan / makan ringan yang baru. Salah satu kunci dari eksistensi tempat usha tersebut pemilik bisa mempertahankan kinerja karyawannya dengan baik, tetapi tidak menutup kemungkinan kalau kinerja karyawan bisa menurun disebabkan 
karena pemilik usaha hanya mementingkan perbaikan produk tetapi dari sisi peran karyawan dan budaya organisasi kurang diperhatikan.

Penelitian ini diharapkan mampu memberikan gambaran yang nyata terhadap peran OCB dan budaya organsasi dalam rangka meningkatkan kinerja karyawan di tempat usaha makanan ringan (snak makroni cap bintang) desa Mutih Wetan Kabupaten Demak. Berdasarkan hasil penelitian tersebut pemilik usaha bisa mengevaluasi apa yang harus dilakukan selanjutnya dalam menumbuhkan perilaku ekstra peran pada karyawannya dan membangun budaya organisasi yang lebih baik lagi. Oleh sebab itu, berdasarkan latar belakang diatas peneliti tertarik untuk melakukan penelitian dengan judul "Peran Organizational Citizenship Behavior (OCB) dan Budaya Organisasi Dalam Meningkatkan Kinerja Karyawan di UKM Snak Makroni Cap Bintang Desa Mutih Wetan Kabupaten Demak".

\section{B. KAJIAN PUSTAKA}

\section{Organizational Citizenship Behavior (OCB)}

Dalam rangka meningkatkan kinerja karyawan dalam organisasi, factor yang sangat mempengaruhi salah satunya adalah perilaku yang di tunjukkan oleh karyawan itu sendiri. Perilaku yang diharapkan tidak selalu berkaitan dengan tugas / pekerjaan yang telah ditetapkan dalam peraturan yang tidak tertulis dalam deskripsi kerja mampu memberikan dampak dan kontribusi yang menguntungkan bagi organisasi.

Robbins (2007) mengemukakan bahwa OCB merupakan perilaku pilihan yang tidak menjadi bagian dari kewajiban kerja formal seorang pegawai, namun mendukung berfungsinya organisasi tersebut secara efektif. Penelitian yang dilakukan oleh Novliadi (2007) OCB berkembang sejalan dengan seberapa besar perhatian organisasi terhadap kontribusi pegawai, sehingga pegawai akan memiliki persepsi yang positif terhadap organisasi dan akan memberikan umpan balik dengan terlibat dalam OCB. Gibson, et al (2011) lebih lanjut memperinci bahwa perilaku organisasional bisa memaksimalkan efisiensi dan produktivitas karyawan maupun organisasi yang pada akhirnya memberi kontribusi pada fungsi efektif dari suatu organisasi.

Bardasarkan penjelasan diatas bisa disimpulkan bahwa OCB adalah suatu sikap diluar sikap formal/in role dan bersifat positif yang dilakukan karyawan secara sukarela/ extra role. Sikap tersebut sangat berguna bagi organisasi / perusahaan untuk tetap mempertahankan eksistensi. Karyawan yang memiliki sikap ekstra peran akan bertanggung jawab, merasa memiliki dan cinta terhadap pekerjaannya. Pekerjaan yang diberikan oleh perusahaan akan diselesaikan secara sukarela tanpa adanya pengawasan karena mereka sudah merasa memiliki sebagai bagian dari perusahaan.

Ada beberapa aspek OCB menurut Organ et all (2006) menjelaskan bahwa:

a. Altruism.

Perilaku menolong rekan kerja yang mengalami kesulitan dalam situasi yang sedang dihadapi mengenai tugas perusahaan maupun masalah pribadi. Aspek ini memberikan pertolongan yang bukan menjadi tanggung jawab dari tugas utama.

b. Conscientiousness.

Perilaku yang menunjukan usaha lebih yang dilakukan karyawan dibandingkan harapan perusahaan. Perilaku ini bersifat sukarela tanpa mempertimbangkan reward maupun penghargaan yang akan diterima.

c. Sportsmanship.

Perilaku toleransi yang diperlihatkan karyawan saat keadaan perusahaan kurang 
ideal tanpa mengajukan keberatan. Perilaku ini mendukung adanya iklim positif dalam pekerjaan karena adanya perilaku lebih sopan dan bekerja sama dengan yang lain.

d. Courtesy.

Menjaga hubungan baik dengan rekan kerjanya agar terhindar dari masalah personal, dan cenderung memperlihatkan perilaku memperdulikan orang lain.

e. Civic Virtue.

Perilaku yang mendedikasikan dirinya kepada tanggung jawab perusahaan seperti mengikuti perubahan dalam organisasi, mengambil inisiatif untuk rekomendasi sebuah perubahan demi efisiensi maupun kemajuan perusahaan.

Organ (1995) dan Sloat (1999) dalam Zurasaka (2008) mengemukakan beberapa factor yang mempengaruhi OCB yaitu :

a. Budaya dan Iklim organisasi

Pada iklim organisasi yang positif, pegawai akan melakukan pekerjaan melebihi apa yang telah disyaratkan dalam uraian pekerjaan.

b. Kepribadian dan suasana hati

Kemauan seseorang untuk membantu orang lain juga dipengaruhi oleh mood. Kepribadian merupakan karakteristik yang dapat dikatakan tetap, sedangkan suasana hati merupakan karakteristik yang dapat diubah-ubah. Sebuah suasana hati yang positif akan meningkatkan peluang seseorang untuk membantu orang lain.

c. Persepsi tentang dukungan organisasional

Persepsi terhadap dukungan organisasional data menjadi predictor OCB. Pekerja yang merasa didukung oleh organisasi akan memberikan timbal balik yang positif.

d. Persepsi kualitas hubungan/interaksi atasan bawahan

e. Masa kerja dan jenis kelamin.

\section{Budaya Organisasi}

Budaya organisasi merupakan kebiasaan dan keyakinan yang dilakukan oleh seseorang karena mengikuti ajaran yang sudah ada. David (2004) menyatakan budaya organisasi adalah pola tingkah laku yang dikembangkan oleh suatu organisasi yang dipelajarinya ketika mengalami masalah adaptasi eksternal dan integrasi internal, yang telah terbukti cukup baik untuk disahkan dan diajarkan kepada anggota baru sebagai cara untuk menyadari, berpikir dan merasa. Sedangkan menurut Schein (1985) dalam Riani (2011:6) budaya organisasi sebagai suatu pola dari asumsi-asumsi dasar yang ditemukan, diciptakan, atau dikembangan oleh suatu kelompok tertentu dengan maksud agar organisasi belajar mengatasi atau menanggulangi masalah-masalahnya yang timbul akibat adaptasi eksternal dan integrasi internal yang sudah berjalan dengan cukup baik, sehingga perlu diajarkan kepada anggota-anggota baru sebagai cara yang benar untuk memahami, memikirkan dan merasakan berkenaan dengan masalahmasalah tersebut. Budaya organisasi dibentuk sendiri oleh suatu kelompok organisasi untuk bergerak dalam mengatasi tantangangantantangan dimasa depan.

Setiap anggota akan berperilaku sesuai dengan budaya yang berlaku, agar diterima oleh lingkungannya. Robbins (2001) mengemukakan, budaya organisasi mengacu ke suatu sistem makna bersama yang dianut oleh anggota-anggota yang membedakan organisasi itu dari organisasi yang lain. Menurut Davis (1994), budaya organisasi adalah pola keyakinan dan nilai-nilai yang dipahami dan dijiwai (shared) oleh 
anggota organisasi sehingga pola tersebut memberikan makna tersendiri bagi organisasi bersangkutan dan menjadi dasar aturan berperilaku dalam organisasi (Achmad Sobirin, 2002).

Banyak definisi budaya organisasi, namun pada dasarnya definisi-definisi tersebut mengacu pada tiga pendekatan (Martin, 1992, dalam Andreas Budi Rahardjo, 2003), yaitu:

1. Integration approach, menyatakan bahwa setiap organisasi mempunyai satu jenis budaya yang mewarnai semua nilai dan kegiatan anggotanya. Pendekatan ini menekankan pada konsensus semua anggota organisasi terhadap satu budaya yang dominan.

2. Differentiation approach, menekankan pada konsensus sub budaya. Pada pendekatan ini dimungkinkan setiap organisasi mempunyai satu atau lebih sub budaya yang masih dapat dibedakan menjadi tiga yaitu sub budaya yang sejalan dan sama dengan budaya perusahaan, sub budaya yang berbeda dengan budaya perusahaan dan sub budaya yang berlawanan dengan budaya perusahaan.

3. Fragmentation approach, pada pendekatan ini tidak ada konsensus antar anggota organisasi dan tidak ada kesamaan atau kesepakatan nilai-nilai yang dianut pada anggota organisasi. Dengan kata lain budaya perusahaan tersebut tidak ada, yang ada nilai-nilai pribadi anggota organisasi.

Pandangan-pandangan tentang budaya organisasi umumnya menekankan pada pentingnya nilai-nilai yang dianut bersama yang menjadi pengikat diantara anggota perusahaan yang memberi pengaruh terhadap perilaku anggota perusahaan. (Stephen $\mathrm{P}$. Robbins 2001:89). Penjelasan di atas menunjukkan bahwa budaya organisasi adalah kebiasaan yang dilakukan oleh organisasi / perusahaan dalam menjalankan aktivitas kerja atau kegiatan. Organisasi satu dengan organisasi lainnya bisa jadi mempunyai kebiasaan yang berbeda walaupun keduanya mempunyai jenis aktifitas yang sama.

Robbins (2001) menyatakan tujuh karakteristik primer yang sama-sama menangkap hakikat dari suatu budaya suatu organisasi yaitu:

1. Inovasi dan pengambilan resiko, sejauh mana karyawan didorong untuk inovatif dan mengambil resiko

2. Perhatian, sejauh mana karyawan diharapkan memperlihatkan prestasi, analisis dan perhatian kepada rincian.

3. Orientasi hasil, sejauh mana manajemen memusatkan perhatian pada hasil bukannya pada teknik dan proses yang digunakan untuk mencapai hasil itu.

4. Orientasi orang, sejauh mana manajemen memperhitungkan efek hasil-hasil pada orang-orang di dalam organisasi itu.

5. Orientasi tim, sejauh mana kegiatan kerja diorganisasikan sekitar tim-tim, bukannya individu-individu.

6. Keagresifan, sejauh mana orang-orang itu agresif dan bukannya santai-santai.

7. Kemantapan, sejauh mana kegiatan organisasi menekankan dipertahankannya status quo dari pada pertumbuhan.

\section{Kinerja Karyawan}

Sebuah organisasi / perusahaan membutuhkan unsur orang (karyawan) sebagai penggerak aktivitas kerja yang ada didalamnya. Perusahaan bisa mempunyai produk berkualitas karena ada karyawan yang melakukan kinerjanya dengan baik. Notoadmojo (2009) mendefinisikan kinerja adalah apa yang dapat dikerjakan oleh seseorang sesuai 
dengan tugas dan fungsinya. Sedangkan menurut Payaman (2005) kinerja adalah tingkat pencapaian hasil atau pelaksanaan tugas tertentu. Tujuan perusahaan bisa dilihat berdasarkan hasil kerja yang dilakukan seorang individu maupun kelompok dalam lingkungan kerjanya.

Menurut Hariandja (2008) kinerja merupakan hasil kerja yang dihasilkan oleh karyawan atau prilaku nyata yang ditampilkan sesuai dengan peranannya dalam organisasi. Karyawan memiliki tanggung jawab dalam pekerjaannya, berdasarkan perannya masing-masing dan peran tersebut diharapkan bisa berjalan dengan baik sesuai dengan tujuan. Sebagaimana yang dinyatakan Rivai dan Basri (2005), kinerja adalah kesediaan seseorang atau kelompok orang untuk melakukan sesuatu kegiatan dan menyempurnakannya sesuai dengan tanggung jawab dengan hasil seperti yang diharapkan.

Mathis dan Jackson (2006:78) mengungkapkan pengukuran kinerja ada dalam lima poin pengukuran yaitu:

1. Quantity of output (jumlah yang dihasilkan) Dalam penilaian ini pengukuran kinerja akan diukur berdasarkan banyaknya standar hasil yang ditetapkan dan kemampuan hasil yang diberikan. Penilaian ini lebih banyak digunakan untuk menilai prestasi karyawan bagian produksi atau teknis.

2. Quality of output (kualitas keluaran) Dalam penilaian kualitas jika diterapkan pada penilaian pekerjaan produksi atau teknis penilaian dilihat dari hasil barang yang dihasilkan, misalnya tidak ada cacat dan sesuai standar. Namun penilaian ini dapat diperluas selain untuk bagian produksi atau teknis saja. Penilaian kualitas dapat dilihat dari ketepatan, keterampilan, ketelitian, dan kerapihan. Jika karyawan teliti dan terampil dalam melakukan kerjaannya maka hasil yang diberikan akan bagus.

3. Timeline of output (jangka waktu output) Ketepatan waktu merupakan pengukuran kinerja yang dapat dilihat dengan mudah. Penyelesaian sebuah output sesuai dengan waktu yang ditentukan merupakan pertanda kinerja yang baik, terlebih lagi bila karyawan dapat mempersingkat waktu proses kerja namun tetap menghasilkan produk atau hasil kerja sesuai dengan standar yang ditentukan.

4. Presence at work (kehadiran di tempat kerja) Tingkat kehadiran biasa dijadikan patokan dalam pengukuran kinerja. Dengan melihat daftar hadir perusahan berasumsi bahwa jika kehadiran karyawan dibawah standar hari kerja yang ditetapkan maka karyawan tidak memberikan kontribusi yang optimal kepada perusahaan. Hal ini dengan mudah dijadikan perhitungan kinerja perusahaan.

5. Cooperativeness (sikap kooperatif) Penilaian sikap dalam kinerja juga diperhatikan dalam teori ini. Karyawan yang memiliki keinginan terlibat dalam segala perubahan yang terjadi dalam organisasi akan lebih kooperatif dalam beradaptasi. Kemampuan ini dinilai dapat memberikan dampak yang baik bagi organisasi.

Sedangkan John Miner mengemukakan bahwa terdapat empat indikator yang dapatdijadikan sebagai tolok ukur dalam menilai kinerja, yaitu:

1. Kualitas, yaitu; tingkat kesalahan, kerusakan dan kecermatan.

2. Kuantitas, yaitu; jumlah pekerjaan yang dihasilkan.

3. Pengunaan waktu dalam kerja, yaitu; tingkat ketidakhadiran, keterlambatan, waktu kerja efektif/ jam kerja hilang.

4. Kerja sama dengan orang lain dalam bekerja. (Sudarmanto: 2014) 
Menurut Mangkunegara : 2013 ada dua faktor yang bisa mempengaruhi pencapaian kinerja, yaitu faktor kemampuan (ability) dan faktor motivasi (motivation).

1. Faktor kemampuan. Secara psikologis, kemampuan (ability) pegawai terdiri atas kemampuan potensi (IQ) dan kemampuan realita (pendidikan). Oleh karena itu, pegawai perlu ditempatkan pada pekerjaan yang sesuai dengan keahliannya.

2. Faktor motivasi. Faktor ini terbentuk dari sikap (attitude) seorang pegawai dalam menghadapi situasi kerja. Motivasi merupakan kondisi yang menggerakkan pegawai kearah pencapaian tujuan orgnisasi (tujuan kerja).

Gibson (dalam Khaerul: 2012) juga menambahkan bahwa terdapat tiga faktor lain yang berpengaruh terhadap kinerja, yaitu:

1. Faktor individu: kemampuan, keterampilan, latar belakang keluarga, pengalaman kerja, tingkat sosial, dan demografi seseorang.

2. Faktor psikologi: persepsi, peran, sikap, kepribadian, motivasi dan kepuasan kerja.

3. Faktor organisasi: struktur organisasi, desain pekerjaan, kepemimpinan, sistem penghargaan (reward system).

Dari uraian di atas dapat disimpulkan bahwa para karyawan dalam organisasi / perusahaan diharapkan bisa memiliki kualitas kerja yang baik, sehingga bisa menjalankan tugas yang diberikan. Disamping memilki kualitas kerja, karyawan juga dapat diandalkan, serta memiliki solidaritas yang tinggi dalam melakukan kerja sama dengan rekan kerjanya. Pimpinan juga harus bisa memotivasi para karyawannya agar selalu memiliki kinerja yang baik dan bisa terus meningkat.

\section{PENELITIAN TERDAHULU}

1. Penelitian yang dilakukan oleh Anna Suzana, dengan judul "Pengaruh Organizational Citizenship Behavior (OCB) Terhadap Kinerja Karyawan (Studi di : PT. Taspen (Persero) Kantor Cabang Cirebon)". Dalam penelitan tersebut dijelaskan bahwa antara organizational citizenship behavior dengan kinerja karyawan berada pada tingkat sangat kuat yang ditunjukkan dengan angka 0,865 dengan arah yang positif. Pengaruh organizational citizenship behavior terhadap kinerja karyawan ditunjukkan dengan angka $74,8 \%$, yang artinya kinerja karyawan dipengaruhi oleh organizational citizenship behavior sebesar $74,8 \%$ dan sisanya dipengaruhi oleh faktor lain yang tidak diteliti dalam penelitian ini. Kemudian, Signifikansi sebesar 0,000 menunjukkan kurang dari 0,05 , yang artinya HA diterima yaitu "organizational citizenship behavior berpengaruh positif terhadap kinerja karyawan di TASPEN Cirebon".

2. Penelitian yang dilakukan oleh Yumna Dalian Putri dan Hamidah Nayati Utami, dengan judul "Pengaruh Organizational Citizenship Behavior (OCB) Terhadap Kinerja" (Studi Pada Tenaga Perawat Ruang Rawat Inap Rumah Sakit Baptis Batu). Dalam penelitian tersebut dijelaskan hasil analisis regresi linier berganda mengenai pengaruh secara simultan (bersama-sama) pada setiap variabel bebas menunjukan variabel Altruism (X1), Conscientiousnes (X2), Sportsmanship (X3), Courtesy (X4), Civic virtue(X5) mempunyai pengaruh yang signifikan secara simultan terhadap kinerja karyawan. Sedangkan hasil penelitian secara parsial (individual) variabel Altruism (X1), Conscientiousnes (X2), Sportsmanship (X3) dan Civic virtue (X5) berpengaruh signifikan terhadap Kinerja Karyawan $(\mathrm{Y})$. Hal ini menunjukan perawat saling membantu perawat lain serta secara sadar membantu mendorong peningkatan kerja. Hasil penelitian pengaruh variabel Courtesy (X3) terhadap Kinerja Karyawan (Y) hasilnaya tidak signifikan. 
3. Penelitian yang dilakukan oleh Nanda Novziransyah, dengan judul "Pengaruh Budaya Organisasi Terhadap Kinerja Karyawan PT. PLN (PERSERO) Kantor Wilayah Sumatera Utara Medan. Dalam penelitian tersebut dijelaskan secara keseluruhan dari sepuluh variabel budaya organisasi ternyata variabel sistem imbalan dan pola komunikasi secara signifikan berpengaruh terhadap kinerja karyawan. Dari dua variabel yang berpengaruh terhadap kinerja karyawan, variabel pola komunikasi merupakan yang paling dominan dan paling berpengaruh dengan nilai koefisien (ß) sebesar 3,084. Variabel yang tidak berpengaruh terhadap kinerja karyawan adalah inisiatif individu, toleransi terhadap tindakan beresiko, pengarahan, integrasi, dukungan manajemen, kontrol, identitas nilai, toleransi terhadap konflik.

Gambar 1. Gambar Kerangka Berfikir

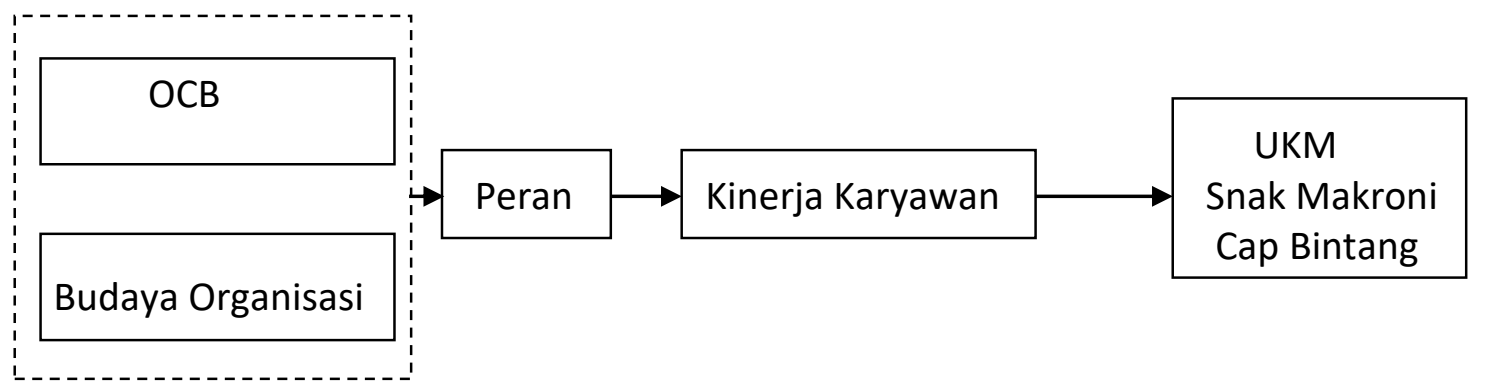

\section{METODE PENELITIAN}

Penelitian yang dilakukan termasuk jenis penelitian lapangan (field research), yaitu studi penelitian yang mengambil data autentik secara obyektif. Sedangkan dilihat dari jenisnya, penelitian ini tergolong penelitian kualitatif dengan menggunakan metode deskriptif. Pendekatan yang dipakai dalam penelitian ini menggunakan teknik pendekatan kualitatif.

Peneliti menggunakan sumber data primer dan sekunder. Sumber data primer adalah sumber data yang langsung memberikan data kepada pengumpul data, misalnya dengan melalui wawancara langsung dengan pimpinan dan karyawan di UKM Snak Makroni Cap Bintang. Adapun sumber data sekunder merupakan sumber yang tidak secara langsung memberikan data kepada pengumpul data misalnya lewat orang lain atau lewat dokumen-dokumen yang dimiliki oleh UKM Snak Makroni Cap Bintang.

Tehnik pengumpulan data melalui metode pengamatan (observasi), wawancara dan dokumentasi. Tehnik analisis data melalui 3 jalur analisis data kualitatif, yaitu dengan reduksi data, penyajian data dan penarikan kesimpulan (Ariesto: 2010) :

1. Reduksi data merupakan bentuk analisis yang menajamkan, menggolongkan, mengarahkan, membuang yang tidak perlu, dan mengorganisasi data sedemikian rupa sehingga kesimpulan akhir dapat diambil.

2. Penyajian data adalah kegiatan ketika sekumpulan informasi disusun, sehingga memberi kemungkinan akan adanya penarikan kesimpulan. Bentuk penyajian data kualitatif berupa teks naratif (berbentuk catatan lapangan), matriks, grafik, jaringan, dan bagan.

3. Penarikan kesimpulan merupakan hasil analisis yang dapat digunakan untuk mengambil tindakan. 


\section{E. PEMBAHASAN}

\section{Peran Organizational Citizenship Behavior (OCB) terhadap Kinerja Karyawan Pada UKM Snak Makroni Cap Bintang, Desa Mutih Wetan, Kabupaten Demak.}

Berdasarkan hasil wawancara dengan pemilik usaha, dapat diketahui bahwa kinerja karyawan di UKM "Snak Makroni Cap Bintang" belum menunjukkan kinerja yang baik secara keseluruhan. Pemilik usaha harus mengetahui peran variabel - variabel yang mendukung dalam peningkatan kinerja karyawan, salah satunya variabel Organizational Citizenship Behavior (OCB). OCB adalah variabel yang dipakai UKM "Snak Makroni Cap Bintang" untuk meningkatkan kinerja karyawan. Penelitian yang dilakukan oleh Deww Zang (2011) dalam Sukmawati mendapatkan hasil yang signifkan, yaitu OCB mempunyai pengaruh positif terhadap kinerja. Adapun peran OCB untuk meningkatkan kinerja karyawan mempunyai lima aspek / indikator menurut Organ el all (2006), yaitu Altruism, Conscientiousness, Sportsmanship, Courtesy dan Civic Virtue.

Karyawan merupakan sumber dari keberhasilan perusahaan, sehingga perlu dikelola dengan tepat dan harus diketahui hubungan baik antar karyawan dalam menjalin kerjasama ditempat kerja. Kerjasama perlu dipupuk dalam diri karyawan sehingga ketika ada masalah yang ada bisa diselesaikan dengan baik. Perilaku tersebut dikenal dengan Altruism, perilaku saling tolong menolong sesama rekan kerja ketika mengalami masalah / kesulitan dalam melaksanakan kegiatan atau tugas yang diberikan perusahaan maupun masalah pribadi. Aspek dalam memberikan pertolongan sebenarnya tidak menjadi tanggung jawab dari tugas utama. Ditemukan untuk aspek ini di UKM "Snak Makroni Cap Bintang" sudah dilakukan tetapi hanya sebatas pertolongan dalam ruanglingkup pekerjaan. Peran perilaku Altruism sangat membantu dalam pelaksanaan kerja. Tentunya pekerjaan akan cepat selesai bila karyawan saling tolong menolong dan akan terjalin hubungan emosional yang baik. Karyawan yang memberikan pertolongan disini tidak menjadi tugas utamanya.

Perilaku Conscientiousness sangat dibutuhkan, yaitu perilaku karyawan yang menunjukkan usaha ekstra dari harapan yang akan diperoleh. Adapun perilaku bersifat sukarela tanpa menginginkan kompentasi dari perusahaan. Karyawan yang memiliki perilaku tersebut akan menyelesaikan pekerjaannya dengan lebih baik dan penuh dengan tanggung jawab, dibandingkan karyawan yang selalu mengharapkan imbalan atas pekerjaannya. Karyawan yang selalu mengharapkan imbalan, jika harapannya tidak sesuai cenderung kinerjanya akan menurun. Perilaku karyawan (Conscientiousness) di UKM “Snak Makroni Cap Bintang” belum terlalu kelihatan, kareana usaha ekstra muncul karena adanya sebuah imbalan yang diberikan.

Perilaku Sportsmanship lebih mengakomodir keadaan yang menimpa di tempat usaha / perusahaan. Perilaku toleransi yang dimiliki karyawan sangat diharapkan karena bisa menjadi solusi ketika perusahaan kurang baik dengan tanpa adanya pengajuan keberatan. Perilaku demikian menjadikan keadaan lebih baik dalam aktivitas kerja, sehingga rasa saling kerja sama masih tetap terjalin. Jangan sampai ada karyawan yang berdemo / protes karena masalah stabiltas perusahaan. Bila hal terbut terjadi tentunya hubungan baik pimpinan dengan karyawan dan karyawan dengan karyawan lainya akan kurang baik, iklim kerja juga akan memburuk. Karyawan UKM "Snak Makroni Cap Bintang" mempunyai toleransi terhadap perusahaan. Ketika keadaan ditempat kerja kurang ideal mereka tidak melakukan protes apalagi demo, aktivitas kerja masih tetap berjalan.

Menjalin hubungan baik dengan rekan kerja supaya terhindar dari masalah 
antar personal dan lebih menunjukkan perilaku peduli terhadap orang lain. Aspek ini salah satu bagian dari OCB dan dikenal dengan Courtesy, yaitu perilaku seorang karyawan yang mau menjalin hubungan baik dan peduli terhadap sesama rekan kerja, hubungan tersebut akan menumbuhkan sikap kekeluargaan. Jalinan tersebut tidak hanya berlaku ditempat kerja melainkan diluar tempat kerja juga akan terus melekat. Karyawan UKM "Snak Makroni Cap Bintang" terlihat sudah menjalin hubungan yang baik antar rekan kerja. Ditunjukkan jika ada salah satu karyawan yang tidak bisa masuk kerja, mereka akan saling tanya dan datang menjenguk jika ada karyawan yang sakit. Dengan melakukan kegiatan tersebut hubungan antar karyawan tetap terbina dengan baik, dan tentunya akan berdampak pada kinerja karyawan.

Perilaku Civic Virtue juga akan berdampak pada kinerja karyawan. Perilaku yang mendedikasikan dirinya untuk perusahaan disertai dengan tanggungjawab, seperti mengikuti perubahan dalam perusahaan dan memberi solusikan demi kemajuan perusahaan. Perilaku karyawan untuk mengabdikan dirinya dan disertai dengan rasa tanggungjawab sangatlah dibutuhkan, karena totalitas dalam melaksanakan kerja akan ada dalam diri karyawan. Karyawan yang secara total melakukan pekerjaannya akan mendapatkan hasil maksimal. Jika perusahaan mengalami perubahan, karyawan cenderung memberikan solusi untuk mempertahankan dan memajukan perusahaannya. Karyawan di UKM "Snak Makroni Cap Bintang" lebih mengikuti perubahan yang terjadi ditempat kerja dan mereka jarang memberikan solusi ketika ada perubahan. Apa yang diputuskan pemilik usaha, karyawan mengikutinya.

\section{Peran Budaya Organisasi terhadap Kinerja Karyawan Pada UKM Snak Makroni Cap Bintang, Desa Mutih Wetan, Kabupaten Demak.}

Peran budaya organisasi sangatlah mempengaruhi kinerja karyawan. Berdasarkan observasi yang dilakukan peneliti dan wawancara, budaya organisasi yang ada di UKM Snak Makroni Cap Bintang kurang dikelola dengan baik. Orientasi masih pada produk yang dihasilkan, dalam hal proses pembuatan produk yang dilakukan oleh para karyawan kurang disentuh. Bagaimana seorang karyawan bisa berinovasi dan melakukan kerja tim secara solid, belum mendapatkan perhatian yang lebih. Peran pemilik usaha dalam membudayakan kegiatan semacam itu sangatlah diperlukan. Budaya organisasi bisa mempengaruhi kinerja karyawan. Seperti penelitian yang dilakukan Luthans dalam Riani, 2011: 8 menyatakan bahwa budaya organisasi yang baik akan menambahkan nilai positif bagi kelancaran kinerja organisasi

Ada beberapa karakteristik budaya organisasi yang bisa mendorong kinerja karyawan. Robbins (2001) menyatakan tujuh karakteristik primer yang sama-sama menangkap hakikat dari suatu budaya suatu organisasi yaitu: inovasi dan pengambilan resiko, perhatian, orientasi orang, orientasi tim, keagresifan dan kemantapan.

Inovasi merupakan ide/gagasan baru yang bisa dipakai untuk memperbaiki produk dan praktik kerja yang bersifat stadnan. Karyawan harus memiliki ide/gagasan untuk mendukung aktivitas kerja. Perkembangan dan kemajuan zaman ditandai dengan teknologi tinggi dan cepatnya perubahan prilaku konsumen harus segera direspon dengan tepat. Perusahaan dituntut untuk melakukan inovasi untuk mendukung eksistensi produk. Dorongan pemilik usaha untuk menumbuhkan gagasan baru (inovasi) pada diri karyawan sangatlah diperlukan. Karyawan yang memiliki inovasi akan bisa mengelola perubahan perilaku konsumen, dengan membuat produk yang diinginkan dan dibutuhkan. Berani mengambil resiko untuk kemajuan perusahaan juga harus 
didukung oleh pemilik usaha. Ketika karyawan terlalu dibatasi dalam pengambilan keputusan biasanya muncul rasa kurang dihargai dalam pekerjaannya. Berdasarkan kajian yang dilakukan, UKM Snak Makroni Cap Bintang dalam mendorong karyawannya untuk berinovasi kurang dilakukan. Bisa terlihat salah satunya pada pengemasan produk sangatlah sederhanya dan kurang menarik. Melihat hal tersebut bisa disimpulkan bahwa inovasi produk kurang diterapkan dengan baik.

Perhatian dari pemilik usaha sangatlah dibutuhkan untuk karyawan yang memiliki prestasi. Dengan perhatian yang diberikan, karyawan merasa dihargai dan akan mengulang prestasi yang pernah dihasilkan. Prestasi kerja yang ditunjukkan oleh seorang karyawan akan mendorong karyawan lain untuk melakukan hal yang sama. Maka sudah saatnya pemilik usaha lebih pemperhatikan karyawannya dengan memberikan reward bila karyawan melakukan tugasnya dengan baik. Pemilik UKM Snak Makroni Cap Bintang cukup memperhatikan karyawannya yang memiliki kinerja baik. Untuk karyawan yang mencapai target tertu, akan mendapatkan bonus. Dengan upaya demikian kinerja karyawan akan meningkat, disini dibutuhkan kerjasama antara pemilik dan karyawan. Karyawan harus menunjukkan prestasinya dan pemilik juga harus memberikan apresiasi untuk prestasi itu.

Orientasi orang dan tim perlu mendapatkan perhatian yang khusus. Perusahaan harus selalu memonitoring apa yang telah dihasilkan secara individu dan tim dalam melakukan tugas/kegiatan yang diberikan. Dalam perusahaan/organisasi adakalanya tugas yang diberikan hanya untuk perorangan tetapi juga ada tugas yang harus diselesaikan secara kelompok/tim. Maka perlu adanya penilaian secara individu dan tim dalam pelaksanaan kerja, sehingga karyawan mempunyai kualitas individual dan kualitas dalam tim kerja/kelompok. Pemilik UKM Snak Makroni Cap Bintang selalu memperhatikan karyawannya dalam melakukan aktivitas kerja. Perhatian yang dilakukan lebih ditekankan pada perorangan, sedangkan untuk tim kerja kurang diperhatian karena memang jenis kegiatan kebanyakan menekankan pada penyelesaian secara individual. Tapi kalau diperhatikan ada kegiatan yang dilakukan secara tim, yaitu pada saat proses penggorengan bahan makroni.

Perilaku agresif bermakna melakukan pekerjaan dengan sungguh-sungguh tidak malas / santai. Pekerjaan diselesaikan dengan segera tidak menunda, sehingga target yang diberikan cepat selesai. Karyawan yang tidak agresif cenderung menunda pekerjaan dan bersikap santai terhadap pekerjaan yang diberikan. Perusahaan mempunyai peran yang penting dalam menertibkan karyawan yang tidak memiliki agresifitas, karena akan berdampak pada hasil kerja yang buruk. Karyawan yang memiliki kinerja yang buruk diberikan motivasi agar lebih baik lagi. Karyawan UKM Snak Makroni Cap Bintang melakukan pekerjaannya dengan agresif walaupun terkadang ada yang kurang tetapi pemilik segera melakukan tindakan dengan menegur karyawan tersebut dan memberikan penjelasan yang mendidik.

Kemantapan perusahaan dalam pempertahankan status quo terkadang perlu dilakukan, sejauh keadaan yang dimiliki menunjukkan stabilitas yang baik. Tidak selamanya perubahan yang cepat itu dilakukan. Perubahan harus disesuaikan dengan kondisi yang ada. Pertumbuhan memang diperlukan tetapi mempertahankan stabilitas juga perlu dilakukan agar tidak terkontaminasi dengan perubahan yang menyebabkan perusahaan berada pada keadaan yang buruk. Perubahan tersebut menekankan kegiatan yang ada diorganisasi. Pemilik UKM Snak Makroni Cap Bintang tetap memutuskan untuk memproduksi makroni dalam usahanya, tidak menambah jenis 
produk lainnya. Disini menunjukkan pemilik mantap tetap mempertahankan status quo dalam hal produk yang dihasilkan.

\section{F. SIMPULAN DAN SARAN}

\section{Simpulan}

Peran Organizational Citizenship Behavior (OCB) akan meningkatkan Kinerja Karyawan di UKM Snak Makroni Cap Bintang, Desa Mutih Wetan, Kabupaten Demak. Ada lima aspek dalam pelaksanaanya OCB, yaitu : Altruism; perilaku saling tolong menolong sesama rekan kerja, baik terkait tugas utama maupun diluar itu, Conscientiousness; perilaku yang menunjukan usaha lebih dari karyawan tanpa mengharapkan reward, Sportsmanship; perilaku toleransi saat keadaan perusahaan kurang ideal dan mendukung iklim yang positif, Courtesy; menjaga hubungan baik dan peduli terhadap rekan kerja, Civic Virtue ; perilaku yang mendedikasikan dirinya kepada tanggung jawab perusahaan dan memberikan masukan demi kemajuan perusahaan.

Peran budaya organisasi akan meningkatkan kinerja karyawan di UKM Snak Makroni Cap Bintang, Desa Mutih Wetan, Kabupaten Demak. Adapun peran budaya organisasi disini ada lima aspek dalam pelaksanaanya, yaitu : inovasi dan pengambilan resiko; sejauh mana karyawan didorong untuk inovatif dan mengambil resiko untuk kemajuan perusahaan, perhatian ; karyawan akan memperlihatkan prestasi kerjanya, orientasi orang ; manajemen akan memperhitungkan efek hasil-hasil pada orang-orang di dalam organisasi itu, orientasi tim ; kegiatan kerja diorganisasikan diarahkan untuk tim-tim, bukannya kerja secara individual, keagresifan; karyawan akan memiliki agresifitas dalam pekerjaannya sehingga tidak akan melakukan kebiasaan santai-santai, kemantapan ; kegiatan organisasi akan menekankan status quo dari pada pertumbuhan, disebabkan karena sudah mempunyai hasil yang baik.

\section{Saran}

\section{a. Untuk UKM Snak Makroni Cap Bintang}

Pemilik UKM Snak Makroni Cap Bintang, Desa Mutih Wetan, Kabupaten Demak harus lebih menyadari dan memperhatikan peran variabel OCB dan budaya organisasi untuk meningkatkan kinerja karyawan. Perilaku ekstra peran yang dimiliki karyawan membantu penyelesaian tugas dengan penuh rasa tanggung jawab tanpa mengharap imbalan dan karyawan akan memiliki toleransi yang tinggi terhadap perusahaan. Kesadaran dari pemilik harus ditingkatkan pada tahap evaluasi kinerja karyawan. Perhatian tidak hanya berorientasi pada produk dan penjualan produk, tetapi juga harus menyentuh pada aspek SDM, sehingga berdampak pada kinerja karyawan. Peran budaya organisasi yang baik juga akan meningkatkan kinerja karyawan. Dalam aktivitas kerja pemilik harus berusaha untuk memancing agar karyawan memiliki perilaku inovatif dengan cara memberikan kebebasan untuk berpendapat dan membuat produk baru, pemilik juga memperhatikan karyawan yang memiliki prestasi kerja yang baik dengan memberikan reward.

\section{b. Untuk Peneliti Selanjutnya}

Untuk penelitian lanjutan, disarankan untuk meneliti pada aspek yang berbeda, contohnya tentang pengalaman kerja, penilaian kinerja dan orientasi kerja dengan pendekatan kuantitatif sehingga menambah khazanah keilmuwan. 
Peran Organizational Citizenship Behavior...

\section{DAFTAR PUSTAKA}

Achmad Sobirin, 2002, "Budaya : Sumber Kekuatan Sekaligus Kelemahan Organisasi". Jurnal Siasat Bisnis, No.7, Vol. 1, Hal. 1-20.

Andreas Budihardjo, 2003, "Peranan Budaya Perusahaan : Suatu Pendekatan Sistematik dalam Mengelola Perusahaan". Jurnal Manajemen Prasetya Mulya, Mei, Vol. VIII, No. 14.

Ariesto Hadi Sutopo dan Adrianus Arief, Terampil Mengolah Data Kualitatif dengan NVIVO, Prenada Media Group, Jakarta, 2010.

David, Fred R. (2004) Manajemen Strategi, Konsep. Edisi Ketujuh, Alih Bahasa Alexander Sindoro, Jakarta: Prehalindo.

Gibson, Ivancevich \& Donnelly. 2011. Perilaku, Struktur, Proses. Il ed. Jakarta:Salemba Empat.

Hafsah, M.J. 2004. Upaya Pengembangan Usaha Kecil dan Menengah (UKM). Jurnal Infokop Nomor 25 Tahun XX

Harianja, Marihot Tua Effendi (2002). Manajemen Sumber Daya Manusia, Pengadaan, Pengembangan, Pengkompensasian, dan Peningkatan Produktivitas Karyawan, Jakarta: Grasindo.

Khaerul Umam, Perilaku Organisasi, Pustaka Setia, Bandung, Cet. 2, 2012.

Luthans F., 1992, Organizational Behavioural, 7th Edition, McGraw-Hill, New York.

Mangkunegara, A. (2011). Manajemen S u mb er Da y a Man u sia. B a n d ung: P T. R e m a j a Rosdakarya.

Mengelola Perusahaan". Jurnal Manajemen Prasetya Mulya, Mei, Vol. VIII, No. 14.

Martin J., 1992, Cultures in Organizations: Three Perspective, Oxford University Press, London.

Notoatmojo, Soekidjo. 2009. "Pengembangan Sumber Daya Manusia". PT Rineka Cipta.Jakarta

Novliadi, F. 2008. Organizational Citizen Behavior Karyawan Ditinjau dari Persepsi Terhadap Kualitas Interaksi Atasan-Bawahan dan Persepsi Terhadap Dukungan Orgnisasional, USU Repository

Organ, D. W., Podsakoff, P. M., \& Mackenzie, S. B. (2006). Organizational citizenship behavior: Its nature, antecedents, and consequences. London: Sage Publications

Payaman (2005) Manajemen, Yogyakarta: Andi Bekerja Sama dengan John wiley dan Sons

Riani, Asri Laksmi. 2011. Budaya Organisasi. Yogyakarta : Graha Ilmu

Rivai, V. dan Basri, A. (2005). Pe rfor man ce Ap pra i s a I. Jakarta: PT. Raja Grafindo Persada.

Robbins S. P.,2001, Perilaku Organisasi : Konsep, Kontroversi, Aplikasi, edisi kedelapan versi Bahasa Indonesia, Jilid 1 \& 2, PT Prenhallindo, Jakarta.

Sudarmanto, Kinerja dan Pengembangan Kompetensi SDM, Pustaka Pelajar, Yogyakarta, 2014

Sukmawati. 2013. "Peran Organizational Citizenship Behavior sebagai Mediator Pengaruh Kepuasan Kerja, Lingkungan Kerja dan Komitmen Organisasi terhadap Kinerja Karyawan". Journal Aplikasi Manajemen.Vol.11,No.4

Suzana, Anna. 2017. Pengaruh Organizational Citizenship Behavior (OCB) Terhadap Kinerja Karyawan. Jurnal Logika, Vol XIX No 1 April 2017

Zurasaka. A $2008 . \quad$ "Teori Perilaku Organisasi". <http://zurasaka.wordpress.com/2008/11/25/perilakuorganisasi>(15/11/18) 